\title{
ОГЛЯДИ
}

УДК 581.192: 633.111.1: 631.8

doi: $10.25128 / 2078-2357.21 .1-2.12$

Ю. Д. МАРЦІНИШИН, С. В. ПИДА

Тернопільський національний педагогічний університет імені Володимира Гнатюка

вул. М. Кривоноса, 2, Тернопіль, 46027

e-mail: spyda@ukr.net

\section{БІОХІМІЧНИЙ СКЛАД ЗЕРНА ПШЕНИЦІ М'ЯКӦ̈ (TRITICUM AESTIVUM L.) ЗА ВПЛИВУ ДОБРИВ}

У статті, на основі аналізу літератури, наведено результати вивчення впливу мінеральних, органічних та органо-мінеральних добрив на біохімічний склад зерна пшениці. Встановлено, що насіннєва продуктивність та якість зерна пшениці залежать від забезпечення рослин елементами живлення протягом вегетації, стійкістю до стресових факторів та біологічними особливостями сорту. Добрива $є$ істотним чинником підвищення показників якості зерна пшениці та хлібопекарського борошна.

За застосування органічних добрив та сидератів виявлено тенденцію до підвищення вмісту клейковини в зерні пшениці озимої. Якість зерна пшениці (поживна цінність і хлібопекарські властивості) також залежить від амінокислотного складу білків. Показано, що азотні добрива підвищують вміст білків у зерні та поліпшують їх амінокислотний склад, але внесення їх, особливо у підвищених дозах, призводить до зниження хлібопекарських властивостей зерна пшениці. Азотні добрива підвищують також вміст мікроелементів у зерні пшениці і покращують поживні якості цього важливого продукту харчування. На фоні мінерального живлення $\left(\mathrm{N}_{60} \mathrm{P}_{60} \mathrm{~K}_{60}\right)$ передпосівна обробка насіння і позакореневе підживлення рослин у фази кущіння і колосіння рідким органо-мінеральним добривом Полідон Біо Зерновий спеціального призначення для пшениці озимої підвищували вміст білків у зерні та сприяли зростанню масової частки сирої клейковини.

Ключові слова: пшениця м'яка, біохімічний склад зерна, білки, клейковина, добрива.

Пшениця - важлива стратегічна культура, яку вирощують в Україні. Вона займає найбільші посівні площі, $\epsilon$ первинною харчовою ланкою забезпечення людини біологічно важливими елементами. Тому активно розробляються біотехнології селекційного процесу, що грунтуються на поєднанні можливостей класичної й молекулярної генетики, що забезпечує радикальне покращення пшениці за кількісним і якісним складом білків. Хліб майбутнього, на думку завідувача відділу генетичних основ селекції Селекційно-генетичного інституту Національного центру насіннєзнавства та сортовивчення НААН України О. І. Рибалки, має бути збалансований за всіма біологічно цінними елементами і мати не лише енергетичне, а й профілактично-лікувальне значення, а сьогодні на цьому особливо наголошує сучасна національна програма здорового харчування України [14].

Однак, успадкований генетичний потенціал сорту не може сам по собі гарантувати відповідну урожайність та якість зерна пшениці озимої, оскільки реалізація потенціалу значно залежить від регульованих (агротехніка) і нерегульованих чинників (сонячна радіація, опади, вологість повітря, температура) довкілля, створення для кожного сорту відповідних умов.

90 ISSN 2078-2357. Наук. зап. Терноп. нац. пед. ун-ту. Сер. Біол., 2021, Т. 81, № 1-2 
Виробництво зерна нестабільне за роками, що зумовлено ускладненням клімату, екстремальними явищами, погіршенням екології й природно-кліматичних умов загалом [28]. Амплітуда коливань вмісту білків у зерні за дії регульованих факторів становить $8 \%$, а нерегульованих $-11 \%$ [16].

Урожайність пшениці озимої за рахунок надсильних та екстрасильних сортів зросла до 10 т/га, проте якість зерна, яка негативно корелює 3 продуктивністю, знизилась. Рівень білковості не перевищує 12,6-13,2\% [5, 12].

Відсоток якісного зерна пшениці озимої в Україні, що відповідає вимогам світових стандартів, становить лише 10-12\% від загальної кількості [28]. Підвищення якості зерна пшениці озимої, що відповідає вимогам світових стандартів, $є$ важливим завданням працівників агропромислового комплексу [5]. Експериментально доведено, що підвищення врожаю та якості отриманої продукції на 50-55\% зумовлено комплексом агротехнологічних заходів (забезпечення рослин елементами живлення протягом вегетації, стійкістю до стресових факторів) і на 25-30 \% - біологічними особливостями сорту [11, 20, 28, 30].

За даним П. П. Вавілова [цит. за 21] пшениця м'яка містить у зерні 13,9 \% білків, 79,9 \% вуглеводів, 2,0 \% жиру, 2,3 \% клітковини та 1,9\% золи. Вміст білків у зерні озимої пшениці може коливатися від 8 до $22 \%$. Вуглеводи в основному представлені крохмалем (48-63\%), частка розчинних цукрів становить 2-7 \%, 2-3\% - клітковина [21].

Вміст білків характеризує не тільки харчову цінність зерна пшениці, але i його технологічні властивості. У якісному зерні зазначений показник має перебувати на рівні від 11 до $17 \%$, тому що за низьких або високих показників якість хлібобулочних виробів, виготовлених з борошна цієї пшениці, різко погіршується [3].

Клейковина або глютен (від лат. Gluten - клей) займає близько $80 \%$ і являє собою складну суміш різних білкових молекул (гліадин і глютенін) [2, 4, 27]. Вміст клейковини також $\epsilon$ важливим показником, оскільки суттєво впливає на якість борошна. Клейковина - це фракції протеїну пшениці, які можна вимити з борошна, тобто це хімічна речовина білкової групи, яка не розчиняється у воді. Вона визначає об'єм хліба та впливає на пружність, еластичність і пористість м'якуша. Ця речовина дуже важлива при виготовленні хліба та випічки. Чим більше клейковини у складі пшениці, тим вища якість зерна.

Переважна частина білків пшеничного зерна - запасні гліадини і глютеніни, які формують клейковину, інші білки в зерні - альбуміни та глобуліни - структурні й ферментні протеїни [24]. Білок у зерні пшениці накопичується в процесі його наливання переважно внаслідок реутилізації азотовмісних сполук із вегетативних органів, синтезованих до і під час цвітіння [22]. У зрілій зернівці практично весь азот міститься в іiі білках.

Зустрічаються суперечливі висновки щодо впливу азотного живлення на якість зерна пшениці. Одні дослідники вважають, що внесення азотних добрив, особливо у підвищених дозах, призводять до зниження хлібопекарських властивостей зерна пшениці, впливаючи на ослаблення клейковини, що пов'язано 3 динамікою накопичення гліадинів і глютенінів у дозріваючому ендоспермі [19]. В процесі азотного живлення відбуваються відповідні зміни в складі білкового комплексу зерна, що знижує його технологічні властивості.

За думкою інших дослідників лінії рослин пшениці з підвищеними хлібопекарськими властивостями зерна різняться за вмістом у листках азоту та білковістю зерна [8]. Виявлено позитивні кореляційні зв'язки між вмістом у листках азоту та білковістю зерна $[13,18,26]$. За внесення азотних добрив у помірних нормах при вирощуванні озимих і ярих зернових культур на грунтах з високими показниками родючості можна отримати якісне зерно. На бідних грунтах, особливо з підвищеною кислотністю, навіть високі норми не завжди поліпшують показники якості зерна [16].

Встановлено, що за застосування $\mathrm{N}_{30}$ на фоні ранньовесняного підживлення озимої пшениці азотом вміст білків у зерні підвищився в середньому на $0,8-2,1 \%$, а сирої клейковини $-2,2-5,2 \%$. При цьому поліпшення якісного складу зерна залежало від дози азоту. Найвищі показники виявлено за сумарного внесення $\mathrm{N}_{90}[6]$.

Внесення кристалону особливого та акварину-5 (водорозчинні NPK добрива 3 магнієм та мікроелементами (B, Cu, Fe, Mn, Mo, Zn - кристалон особливий; B, Fe, Mn, Mo, Zn - акварин-5)

ISSN 2078-2357. Наук. зап. Терноп. нац. пед. ун-ту. Сер. Біол., 2021, Т. 81, № 1-2 
в хелатній формі) на фонах ранньовесняного підживлення, внесення азоту рано навесні і на початку виходу рослин у трубку сприяло поліпшенню показників якості зерна озимої пшениці. Найвищу якість зерна виявлено за позакореневого підживлення зазначеними вище добривами у фазах виходу в трубку та колосіння на всіх досліджуваних фонах $\left(\mathrm{N}_{30}, \mathrm{~N}_{60}, \mathrm{~N}_{90}\right)$ внесення азоту [6].

Вміст білків визначає харчову цінність, проте не завжди корелює 3 хлібопекарськими властивостями, які залежать від біохімічних особливостей та фізико-хімічних параметрів білково-клейковинного комплексу [24]. Вміст білків та властивості клейковини значною мірою генетично детерміновані, однак умови вирощування також можуть у певних межах модифікувати зазначені вище показники. Насамперед це стосується забезпеченості рослин азотом, оскільки більша частина цього елемента входить до складу амінокислот і білків структурних, ферментних, запасних [37].

Проведені порівняльні дослідження 3 оцінки різних видів мінеральних і органічних добрив і їх впливу на технологічні якості зерна, а саме на вміст білків у зерні і клейковини показали, що за дослідженими показниками добрива $є$ істотним чинником підвищення якості зерна пшениці та хлібопекарського борошна.

За застосування різних видів органічних добрив (гній великої рогатої худоби, курячий послід) та сидератів (віко-пшеничний, вівсяно-гороховий, гірчиця) встановлено тенденцію до підвищення вмісту клейковини з 24,2 до $25,6-27,7$ \% в зерні пшениці озимої [23]. Найкращий результат за впливом на вміст клейковини в зерні пшениці озимої отримано у варіанті із застосуванням підстилкового посліду в дозі 5 т/га.

За дослідженнями Н. П. Бакаєвої [1], застосування гною в дозі 40 т/га підвищувало вміст білків у зерні з $14,8 \%$ (контроль) до $15,6 \%$, застосування мінеральних добрив у дозі $\mathrm{N}_{60} \mathrm{P}_{60} \mathrm{~K}_{60}$ мало найменший ефект - вміст білків у зерні пшениці підвищився до 15,2 \%.

Досліджено [17], що вміст білків гліадінової (проламінової) фракції у варіанті без застосування добрив становив $6,2 \%$, застосування азотних добрив у дозі $\mathrm{N}_{80}$ збільшило зазначений вище показник до $6,9 \%$, кількість білків у глютеніновій фракції змінювалася несуттєво і перевищувала контроль в середньому на $0,2 \%$.

Якість зерна пшениці (поживна цінність і хлібопекарські властивості) також залежить від амінокислотного складу білка. За дослідженнями О.В.Костина та О. М. Церковнової [9] обробка насіння регулятором росту, рідким імуностимулятором та біофунгіцидом з розрахунку 2 л розчину на 1 ц на фоні мінеральних добрив $\mathrm{N}_{100} \mathrm{P}_{70} \mathrm{~K}_{70}$ покращувала якість зерна пшениці озимої. Мінеральні добрива вносили тричі за вегетацію: під час основного обробітку грунту $\mathrm{N}_{40} \mathrm{P}_{50} \mathrm{~K}_{70}$, при посіві $-\mathrm{P}_{20}$, ранньовесняне підживлення $-\mathrm{N}_{60}$. Для обробки насіння застосовували регулятор росту у вигляді розчину пектину $(0,05 \%$ концентрації) виділеного 3 Amaranthus cruentus. За хімічною природою пектин являє собою емульсію, до складу якої входить Д-галактуронова кислота. Універсальний антистресовий рідкий імуностимулятор Гумі із набором необхідних мікроелементів та Фітоспорин - рідкий біофунгіцид, що пригнічує в рослинах розвиток хвороб завдяки антибіотичним властивостям.

Обробка насіння вище зазначеними препаратами підвищила кількість білків у зерні на 0,8-1,4\%. За внесення мінеральних добрив показник суми незамінних амінокислот в зерні пшениці озимої збільшився на 8,4 \% (з 32,18 до 34,88 мг/г). При цьому вміст лізину зріс з 3,20 (на контролі) до 3,73 мг/г (на мінеральному фоні), триптофану - з 1,48 до 1,73, лейцину - 37,43 до 8,40, ізолейцину - 3 3,08 до 3,33, треоніну - 3 3,58 до 3,83, валіну - 35,85 до 5,98, фенілаланіну - 3 6,35 до 6,43, метіоніну - 31,23 до 1,48 мг/г. Обробка насіння регуляторами росту сприяла збільшенню кількості незамінних амінокислот в зерні. Максимальний вміст суми незамінних амінокислот - 38,3 мг/г (на 9,8 \% вище за контроль) відзначено у варіанті із застосуванням імуностимулятора Гумі на фоні мінеральних добрив.

Біологічна цінність i ступінь засвоєння білків визначається за лімітуючими амінокислотами. Дослідження показали, що першою лімітуючою амінокислотою є лізин, другою - треонін. Під дією регуляторів росту відбувалося збільшення цих амінокислот, за винятком біофунгіциду Фітоспорину. 
Практичний досвід показує, що є хвороби, безпосередньо пов'язані з харчуванням [13]. Споживання неочищених зернових продуктів, як відомо, $\epsilon$ профілактикою хронічних захворювань. Цілісні зерна злаків містять важливі для здоров'я людини поживні речовини, а також мінерали і вітаміни, тому, увага до злаків як до джерела біоактивних і функціональних інгредієнтів за останні роки збільшилася.

Мікроелементний склад зерна пшениці озимої важливий показник його біологічної цінності [15]. Добова потреба людини в марганці становить 4 мг/кг, залізі - 10-20, міді - 3, цинку - 15, кобальті - 3 мг/кг маси тіла [13]. Вміст мікроелементів у зрілому зерні і варіабельність мікроелементного складу рослин в основному визначаються генотипними особливостями культур [5], віком рослин та екологічними чинниками [32, 38]. Надмірному накопиченню неорганічних елементів у насінні і плодах запобігають бар'єрні функції вегетативних органів [39]. Відхилення вмісту мікроелементів у вегетативній масі рослин і зерні від оптимального порушує баланс неорганічних елементів [40].

У зерні пшениці вміст заліза під дією зовнішніх факторів може змінюватися від 20 до 60 мг/кг сухої речовини, цинку - від 22 до 33, кобальту - від 0,5 до 1,1, міді - від 1,7 до 3,2, марганцю - від 38 до 55 мг/кг сухої речовини $[10,31,39]$.

Хімічний склад і фізичні властивості зерна пшениці озимої змінюється в процесі дозрівання і залежить від ступеня зрілості. Зерна пшениці при дозріванні містять багато цінних речовин, які зникають або зменшуються їх унікальні властивості в зрілих ядрах. Зерна пшениці зібрані до дозрівання містять у своєму складі значно менше крохмалю, більше вітамінів групи В (B1, В2, B3, В6), вітаміну С, мікроелементів та цукру [34, 36, 41, 42]. Таким чином, зерна пшениці зібрані у фазу молочно-воскової стиглості $є$ цінним інгредієнтом для виробництва функціонального харчування.

Досліджено, що азотні добрива підвищують вміст мікроелементів в зерні пшениці і покращують поживні якості цього важливого продукту харчування. В умовах 8-річного польового досліду (1999-2007 рр.) за внесення азотних добрив у дозах $\mathrm{N}_{130}$ та $\mathrm{N}_{300}$ спостерігалася тенденція до збільшення вмісту заліза $(\mathrm{Fe})$, цинку $(\mathrm{Zn})$ і міді $(\mathrm{Cu})$ в зерні пшениці озимої порівняно з контролем [35]. Концентрація мікроелементів була найвищою в висівках і найнижчою - у борошні. Застосування підвищеної дози азоту збільшувало вміст Zn i $\mathrm{Cu}$ у борошні та спостерігалося збільшення концентрації $\mathrm{Fe}$ лише у висівках. Також встановлено, що внесення азотних добрив не впливало на концентрацію марганцю (Mn) в зерні пшениці озимої. Азотні добрива змінювали співвідношення $\mathrm{Fe}$ i $\mathrm{Cu}$ в борошні і висівках, але не впливали на розподіл Zn.

Досліджено, що включення в метаболізм рослин пшениці озимої мікроелементів, пов'язаних з азотним обміном $(\mathrm{Cu}, \mathrm{Mo}, \mathrm{Zn})$ підвищує вміст білків і сирої клейковини в зерні та покращує хлібопекарські властивості борошна [39].

Встановлено, що позакореневе підживлення пшениці озимої у фазу кущіння та колосіння хелатним мікродобривом, що містить у своєму складі $\mathrm{Zn}, \mathrm{Cu}, \mathrm{B}, \mathrm{Mo}$, Сo, на фоні повного мінерального живлення $\left(\mathrm{N}_{60} \mathrm{P}_{60} \mathrm{~K}_{60}\right)$ збільшує вміст білка з 12,4 до $13,1 \%$, вміст клейковини 3 25,4 до 29,8 \% [10]. При цьому спостерігалось підвищення вмісту цинку з 20,5 (на контролі) до 21,8 мг/кг, кобальту - 3 0,6 до 0,9, міді з 2,1 до 2,6, марганцю - з 39,8 до 44,6 та заліза - 3 25,7 до 34,7 мг/кг.

Серед великого асортименту рідких комплексних добрив, які стали невід'ємною частиною технології вирощування сільськогосподарських культур, все частіше знаходять застосування агрохімікати цільового використання, склад яких підібраний з урахуванням потреб і фізіологічних особливостей розвитку конкретної культури $[10,23,25,29,31]$.

За результатами визначення вмісту неорганічних елементів методом мас-спектрометрії у зразках рослин пшениці озимої сортів Смуглянка і Подолянка встановлено, що сучасні композиційні ретарданти (синтетичні регулятори росту і розвитку інгібіторного типу 3 антигібереліновим механізмом діiі) впливають на елементний склад рослин протягом вегетації, а також змінюють вміст неорганічних елементів у зерні [31]. Дослідження виконані в період 3 2015 по 2018 роки показали, що пшениця озима м'яка середньорослого сорту Подолянка інтенсивного типу чутливіше реагувала на обробку комплексним біостимулятором та 
ретардантами, ніж короткостебловий високоінтенсивний сорт Смуглянка. Позакореневе підживлення рослин пшениці озимої ретардантами (терпал, медакс топ) сприяла підвищенню в зерні вмісту марганцю, заліза, цинку і міді. За обробки рослин пшениці ретардантами та їх композиціями з мегафолом накопичення заліза в зерні обох сортів зростало до 31-38 мг/кг. У зерні рослин сорту Смуглянка, оброблених препаратом на основі амінокислот гідролізатів рослин мегафол, вміст заліза підвищувався до 45,5 мг/кг сухої речовини.

За дослідженнями О.В. Семенюк [25], на фоні мінерального живлення $\left(\mathrm{N}_{60} \mathrm{P}_{60} \mathrm{~K}_{60}\right)$ передпосівна обробка насіння і позакореневе підживлення рослин у фази кущіння і колосіння рідким органо-мінеральним добривом Полідон Біо Зерновий спеціального призначення для пшениці озимої підвищували вміст білків у зерні за варіантами досліду на 7,0-11,4\%, зростання масової долі сирої клейковини становило $2,4 \%$.

Аналіз літературних джерел показав, що проблема якості зерна є однією з вирішальних для пшениці як культури, що становить фундамент продовольчого забезпечення мільярдів людей. Пріоритетне значення в сучасних умовах мають дослідження 3 розробки та впровадження нових видів добрив, які б забезпечували високу якість зернової продукції. Використання добрив є вагомим чинником поліпшення якісних показників зерна пшениці м’якої, зокрема, кількісного та якісного складу білків і клейковини.

1. Бакаева Н. П. Белково-протеазный комплекс зерна в агротехнологии озимой пшеницы при применении минеральных и органических удобрений. Вестник Ульяновской Государственной сельскохозяйственной академии. 2018. № 4. С. 71-76. DOI 10.18286/1816-4501-2018-4-71-76.

2. Балюбаш В. А., Алёшичев С. Е., Назарова В. В. Определение количества клейковины в пшеничной хлебопекарной муке. Хлебопродукты. 2014. № 7. С. 46-47.

3. Бильдиева Е. А., Нешин И. В. Агрохимические приемы, повышающие качество зерна озимой пшеницы. Агрохимический вестник. 2008. № 3. С. 28-30.

4. Васюсина Т. В., Кравцова Б. Е., Мартьянова А. И. Качество клейковины зерна мягкой пшеницы как показатель его хлебопекарных достоинств. Труды ВНИИЗ. 1972. № 74. С. 106-112.

5. Вплив сортових особливостей на якість зерна пшениці озимої / Г. П. Жемела та ін. Вісник Полтавської Державної Академії. 2020. № 3. С. 32-39. DOI: 10.31210/visnyk2020.03.03.

6. Городній М. М., Макаренко М. В. Показники якості озимої пшениці, вирощеної на лучночорноземному карбонатному грунті. Живлення рослин: теорія і практика (зб. наук. пр., присвяч. 100річчю від дня народж. акад. АН УРСР та ВАСГНІЛ П. А. Власюка) / голов. ред. В. В. Моргун. К. : Логос, 2005. С. 50-60.

7. Киризий Д. А. Эффективность использования азота при фотосинтетической ассимиляции $\mathrm{CO}_{2}$ в листьях пшеницы. Физиология растений и генетика. 2013. № 4. С. 296-305.

8. Кірізій Д. А. Інтенсивність фотосинтезу та продуктивність рослин озимої пшениці залежно від азотного статусу листків. Физиология и биохимия культурных растений. 2012. № 5. С. 399-407.

9. Костин О. В., Церковнова О. М. Биохимический состав и качество зерна озимой пшеницы в зависимости от минеральных удобрений и росторегуляторов. Нива Поволжья. 2009. № 1 (10). С. 19-22.

10. Кутова А. М. Вплив добрив на продуктивність і якість зерна озимої пшениці. Вісник аграрної науки. 2010. № 9. С. 64-67.

11. Ларченко К. А., Морхун Б. В. Признаки качества зерна пшеницы и методы их улучшения. Физиология и биохимия культурных растений. 2010. № 42 (6). С. 463-474.

12. Литвиненко М., Лифенко С. Сила сорту. The Ukrainian Farmer. 2014. № 8 (56). С. 16-19.

13. Микроэлементозы человека: этиология, классификация, органопатология / Авцын А. П., Жаворонков А. А., Риш М. А., Строчкова Л. С. Москва : Медицина, 1991. 496 с.

14. Моргун В. В., Коць С. Я. Фізіологія рослин: досягнення та нові напрямки розвитку (за матеріалами V з’їзду Українського товариства фізіологів рослин). Физиология растений и генетика. 2017. № 5. T. 49. C. $452-459$.

15. Моргун В.В., Швартау В.В., Киризий Д. А. Физиологические основы формирования высокой продуктивности зерновых злаков. Физиология и биохимия культурных растений. 2010. № 5. С. 371-392.

16. Наукові основи ведення зернового господарства. Сайко В. Ф. та ін. За ред. Сайка В. Ф. Київ : Урожай, 1994. 336 с.

17. Насырова Ю. Г., Киселева М. Ю. Влияние протеолитической и амилолитической активности зерна на качество хлеба из пшеничной муки. Успехи современной науки и образования. 2016. Том 1. № 4. C. 6-9. 
18. Особливості фотосинтезу і продукційного процесу у високоінтенсивних генотипів озимої пшениці / Кірізій Д. А. та ін. Київ : Основа, 2011. 416 с.

19. Оценка качества муки озимой пшеницы в процессе селекции / В. П. Нецветаев и др. Достижения науки и техники АПК. 2010. № 11. С. 49-52.

20. Пальчук Н. С. Формування врожайності сортів пшениці озимої при вирощуванні після сої в умовах Північної частини Степу України. Вісник Аграрної науки Причорномор’я. 2014. № 4. С. 156-162.

21. Петриченко В. Ф., Лихочвор В. В. Рослинництво. Нові технології вирощування польових культур. Львів : НВФ «Українські технології», 2020. 806 с.

22. Починок В. М., Кірізій Д. А. Продуктивність і якість зерна пшениці у зв'язку з особливостями розподілу азоту в рослині. Физиология и биохимия культурных растений. 2010. № 5. С. 393-402.

23. Приходько А. В., Сусский А. Н., Моляр С. А. Влияние различных видов органических удобрений на показатели урожайности и качества зерна пшеницы озимой в условиях Степного Крыма. Таврический вестник аграрной науки. 2017. № 4 (12). С. 98-106.

24. Рибалка О. І. Якість пшениці та їі поліпшення: монографія. Київ: Логос, 2011. 496 с.

25. Семенюк О. В. Перспектива применения органоминерального удобрения специального назначения Полидон Био Зерновой при выращивании озимой пшеницы. Известия Горского Государственного Аграрного Университета. 2020. № 2. Т. 57. С. 33-39.

26. Тарасюк О. І., Починок В. М. Вміст у листках азоту та продуктивність ліній озимої м'якої пшениці, унікальних за хлібопекарськими властивостями. Физиология растений и генетика. 2015. Т. 47 . № 1. C. 66-73.

27. Тильба В. А., Ющенко Б. И. Проблемы улучшения качества зерновой продукции в Приамурье. Достижения науки и техники АПК. 2010. № 11. С. 34-37.

28. Урожайність пшениці озимої залежно від системи удобрення та погодних умов вегетаційного періоду / О. В. Бараболя та ін. Вісник Уманського національного університету садівництва. 2018. № 2. С. 3-9.

29. Урожайность и качество зерна озимой пшеницы в зависимости от гуминового удобрения Гумостим и предшественников / С. В. Богомазов и др. Нива Поволжья. 2020. № 3 (56). С. 44-49.

30. Фактори впливу на якість зерна та борошна нових сортів пшениці м'якої озимої / Н. В. Василенко та ін. Миронівський вісник. 2016. № 2. С. 214-225.

31. Швартау В. В., Михальська Л. М., Маковейчук Т. І. Вміст мікроелементів у рослинах озимої пшениці за дії ретардантів. Физиология растений и генетика. 2018. № 6. Т. 50. С. 474-483. URL: https://doi.org/10.15407/frg2018.06.474.

32. Berry P. M., Spink J. Predicting yield losses caused by lodging in wheat. Field Crops Research. 2012. № 137. P. 19-26.

33. Cakmak I., Kutman B. Agronomic biofortification of cereals with zinc: a review. European Journal of Soil Science. 2018. № 69. P. 172-180.

34. Comparison of nutritional compounds in premature green and mature yellow whole wheat in Korea / D. Yang et al. Cereal Chemistry. 2012. № 89 (6). P. 284-289.

35. Influence of long-term nitrogen fertilization on micronutrient density in grain of winter wheat (Triticum aestivum L.) / R. Shib et al. Journal of Cereal Science. 2010. V. 51. P. 165-170. URL: https://doi.org/10.1016/j.jcs.2009.11.008.

36. Investigation of Total Dietary Fiber, Vitamin B1 and B2 Content in Whole-grain Pasta / S. Kalnina et al. Baltic Conference on Food Science and Technology. 2015. P. 133-137.

37. Lawlor D. W. Carbon and nitrogen assimilation in relation to yield: mechanisms are the key to understanding production systems. Journal of Experimental Botany. 2002. № 370. P. 773-787.

38. Manganese deficiency in wheat genotypes: Physiological responses and manganese deficiency tolerance index / A. Barman et al. Journal of Plant Nutrition. 2017. № 19. P. 2691-2708. URL: https://doi.org/10.1080/01904167.2017.1381717.

39. Marschner H. Marschner's mineral nutrition of higher plants. London: Academic Press, 2012. 672 p.

40. Nieder R., Benbi D. K., Reichl, F.X. Microelements and their role in human health. Soil Components and Human Health. Dordrecht: Springer, 2018. P. 317-374.

41. Petrovska-Avramenko N., Karklina D., Gedrovica I. Investigation of immature wheat grain chemical composition. Research for Rural Development. Food Sciences. 2016. V. 1. P. 102-105.

42. Properties of the protein and carbohydrate fractions in immature wheat kernels / S. Iametti et al. Journal of agricultural and food chemistry. 2006. № 54. P. 10239-10244. 


\section{References}

1. Bakaeva N. P. Belkovo-proteaznыi kompleks zerna v ahrotekhnolohyy ozymoi pshenytsы pry prymenenyy myneralnыkh y orhanycheskykh udobrenyi. Vestnyk Ulianovskoi Hosudarstvennoi selskokhoziaistvennoi akademyy. 2018. № 4. S. 71-76. DOI 10.18286/1816-4501-2018-4-71-76. [in Russian]

2. Baliubash V. A., Alëshychev S. E., Nazarova V. V. Opredelenye kolychestva kleikovynы v pshenychnoi khlebopekarnoi muke. Khleboproduktbl. 2014. № 7. S. 46-47. [in Russian]

3. Byldyeva E. A., Neshyn Y. V. Ahrokhymycheskye pryemы, povыshaiushchye kachestvo zerna ozymoi pshenytsы. Ahrokhymycheskyi vestnyk. 2008. № 3. S. 28-30. [in Russian]

4. Vasiusyna T. V., Kravtsova B. E., Martianova A. Y. Kachestvo kleikovynы zerna miahkoi pshenytsы kak pokazatel eho khlebopekarnыkh dostoynstv. Trudbl VNYYZ. 1972. № 74. S. 106-112. [in Russian]

5. Vplyv sortovykh osoblyvostei na yakist zerna pshenytsi ozymoi / H. P. Zhemela ta in. Visnyk Poltavskoi Derzhavnoi Akademii. 2020. № 3. S. 32-39. DOI: 10.31210/visnyk2020.03.03. [in Ukrainian]

6. Horodnii M. M., Makarenko M. V. Pokaznyky yakosti ozymoi pshenytsi, vyroshchenoi na luchnochornozemnomu karbonatnomu grunti. Zhyvlennia roslyn: teoriia i praktyka (zb. nauk. pr., prysviach. 100richchiu vid dnia narodzh. akad. AN URSR ta VASHNIL P. A. Vlasiuka) / holov. red. V. V. Morhun. K. : Lohos, 2005. S. 50-60. [in Ukrainian]

7. Kyryzyi D. A. Эffektyvnost yspolzovanyia azota pry fotosyntetycheskoi assymyliatsyy SO2 v lystiakh pshenytsы. Fyzyolohyia rastenyi y henetyka. 2013. № 4. S. 296-305. [in Russian]

8. Kirizii D. A. Intensyvnist fotosyntezu ta produktyvnist roslyn ozymoi pshenytsi zalezhno vid azotnoho statusu lystkiv. Fyzyolohyia y byokhymyia kulturnblkh rastenyi. 2012. № 5. S. 399-407. [in Ukrainian]

9. Kostyn O. V., Tserkovnova O. M. Byokhymycheskyi sostav y kachestvo zerna ozymoi pshenytsы v zavysymosty ot myneralnыkh udobrenyi y rostorehuliatorov. Nyva Povolzhia. 2009. № 1 (10). S. 19-22. [in Russian]

10. Kutova A. M. Vplyv dobryv na produktyvnist i yakist zerna ozymoi pshenytsi. Visnyk ahrarnoi nauky. 2010. № 9. S. 64-67. [in Ukrainian]

11. Larchenko K. A., Morkhun B. V. Pryznaky kachestva zerna pshenytsы у metodы ykh uluchshenyia. Fyzyolohyia y byokhymyia kulturnblkh rastenyi. 2010. № 42 (6). S. 463-474. [in Russian]

12. Lytvynenko M., Lyfenko S. Syla sortu. The Ukrainian Farmer. 2014. № 8 (56). S. 16-19. [in Ukrainian]

13. Mykroэlementozы cheloveka: эtyolohyia, klassyfykatsyia, orhanopatolohyia / Avtsыn A. P., Zhavoronkov A. A., Rysh M. A., Strochkova L. S. Moskva : Medytsyna, 1991. 496 s. [in Russian]

14. Morhun V. V., Kots S. Ya. Fiziolohiia roslyn: dosiahnennia ta novi napriamky rozvytku (za materialamy V zizdu Ukrainskoho tovarystva fiziolohiv roslyn). Fyzyolohyia rastenyi y henetyka. 2017. № 5. T. 49. S. 452-459. [in Ukrainian]

15. Morhun V. V., Shvartau V. V., Kyryzyi D. A. Fyzyolohycheskye osnovы formyrovanyia vыsokoi produktyvnosty zernovыkh zlakov. Fyzyolohyia y byokhymyia kulturnblkh rastenyi. 2010. № 5. S. 371-392. [in Russian]

16. Naukovi osnovy vedennia zernovoho hospodarstva. Saiko V. F. ta in. Za red. Saika V. F. Kyiv : Urozhai, 1994. 336 s. [in Ukrainian]

17. Nashrova Yu. H., Kyseleva M. Yu. Vlyianye proteolytycheskoi y amylolytycheskoi aktyvnosty zerna na kachestvo khleba yz pshenychnoi muky. Uspekhy sovremennoi nauky y obrazovanyia. 2016. Tom 1. № 4. S. 6-9. [in Russian]

18. Osoblyvosti fotosyntezu i produktsiinoho protsesu u vysokointensyvnykh henotypiv ozymoi pshenytsi / Kirizii D. A. ta in. Kyiv : Osnova, 2011.416 s. [in Ukrainian]

19. Otsenka kachestva muky ozymoi pshenytsы v protsesse selektsyy / V. P. Netsvetaev y dr. Dostyzhenyia nauky y tekhnyky APK. 2010. № 11. S. 49-52. [in Russian]

20. Palchuk N. S. Formuvannia vrozhainosti sortiv pshenytsi ozymoi pry vyroshchuvanni pislia soi v umovakh Pivnichnoi chastyny Stepu Ukrainy. Visnyk Ahrarnoi nauky Prychornomoria. 2014. № 4. S. 156-162. [in Ukrainian]

21. Petrychenko V. F., Lykhochvor V. V. Roslynnytstvo. Novi tekhnolohii vyroshchuvannia polovykh kultur. Lviv : NVF «Ukrainski tekhnolohii», 2020. 806 s. [in Ukrainian]

22. Pochynok V. M., Kirizii D. A. Produktyvnist i yakist zerna pshenytsi u zviazku z osoblyvostiamy rozpodilu azotu v roslyni. Fyzyolohyia y byokhymyia kulturnblkh rastenyi. 2010. № 5. S. 393-402. [in Ukrainian]

23. Prykhodko A. V., Susskyi A. N., Moliar S. A. Vlyianye razlychnыkh vydov orhanycheskykh udobrenyi na pokazately urozhainosty y kachestva zerna pshenytsы ozymoi v uslovyiakh Stepnoho Krыma. Tavrycheskyi vestnyk ahrarnoi nauky. 2017. № 4 (12). S. 98-106. [in Russian]

24. Rybalka O. I. Yakist pshenytsi ta yii polipshennia: monohrafiia. Kyiv : Lohos, 2011. 496 s. [in Ukrainian] 
25. Semeniuk O. V. Perspektyva prymenenyia orhanomyneralnoho udobrenyia spetsyalnoho naznachenyia Polydon Byo Zernovoi pry vыrashchyvanyy ozymoi pshenytsы. Yzvestyia Horskoho Hosudarstvennoho Ahrarnoho Unyversyteta. 2020. № 2. T. 57. S. 33-39. [in Russian]

26. Tarasiuk O. I., Pochynok V. M. Vmist u lystkakh azotu ta produktyvnist linii ozymoi miakoi pshenytsi, unikalnykh za khlibopekarskymy vlastyvostiamy. Fyzyolohyia rastenyi y henetyka. 2015. T. 47. № 1. S. 6673. [in Ukrainian]

27. Tylba V. A., Yushchenko B. Y. Problemb uluchshenyia kachestva zernovoi produktsyy v Pryamure. Dostyzhenyia nauky y tekhnyky APK. 2010. № 11. S. 34-37. [in Russian]

28. Urozhainist pshenytsi ozymoi zalezhno vid systemy udobrennia ta pohodnykh umov vehetatsiinoho periodu / O. V. Barabolia ta in. Visnyk Umanskoho natsionalnoho universytetu sadivnytstva. 2018. № 2. S. 3-9. [in Ukrainian]

29. Urozhainost y kachestvo zerna ozymoi pshenytsы v zavysymosty ot humynovoho udobrenyia Humostym y predshestvennykov / S. V. Bohomazov y dr. Nyva Povolzhia. 2020. № 3 (56). S. 44-49. [in Russian]

30. Faktory vplyvu na yakist zerna ta boroshna novykh sortiv pshenytsi miakoi ozymoi / N. V. Vasylenko ta in. Myronivskyi visnyk. 2016. № 2. S. 214-225. [in Ukrainian]

31. Shvartau V. V., Mykhalska L. M., Makoveichuk T. I. Vmist mikroelementiv u roslynakh ozymoi pshenytsi za dii retardantiv. Fyzyolohyia rastenyi y henetyka. 2018. № 6. T. 50. S. 474-483. URL: https://doi.org/10.15407/frg2018.06.474. [in Ukrainian]

32. Berry P. M., Spink J. Predicting yield losses caused by lodging in wheat. Field Crops Research. 2012. № 137. P. 19-26.

33. Cakmak I., Kutman B. Agronomic biofortification of cereals with zinc: a review. European Journal of Soil Science. 2018. № 69. P. 172-180.

34. Comparison of nutritional compounds in premature green and mature yellow whole wheat in Korea / D. Yang et al. Cereal Chemistry. 2012. № 89 (6). P. 284-289.

35. Influence of long-term nitrogen fertilization on micronutrient density in grain of winter wheat (Triticum aestivum L.) / R. Shib et al. Journal of Cereal Science. 2010. V. 51. P. 165-170. URL: https://doi.org/10.1016/j.jcs.2009.11.008.

36. Investigation of Total Dietary Fiber, Vitamin B1 and B2 Content in Whole-grain Pasta / S. Kalnina et al. Baltic Conference on Food Science and Technology. 2015. P. 133-137.

37. Lawlor D.W. Carbon and nitrogen assimilation in relation to yield: mechanisms are the key to understanding production systems. Journal of Experimental Botany. 2002. № 370. P. 773-787.

38. Manganese deficiency in wheat genotypes: Physiological responses and manganese deficiency tolerance index / A. Barman et al. Journal of Plant Nutrition. 2017. № 19. P. 2691-2708. URL: https://doi.org/10.1080/01904167.2017.1381717.

39. Marschner H. Marschner's mineral nutrition of higher plants. London: Academic Press, 2012. 672 p.

40. Nieder R., Benbi D. K., Reichl, F.X. Microelements and their role in human health. Soil Components and Human Health. Dordrecht: Springer, 2018. P. 317-374.

41. Petrovska-Avramenko N., Karklina D., Gedrovica I. Investigation of immature wheat grain chemical composition. Research for Rural Development. Food Sciences. 2016. V. 1. P. 102-105.

42. Properties of the protein and carbohydrate fractions in immature wheat kernels / S. Iametti et al. Journal of agricultural and food chemistry. 2006. № 54. P. 10239-10244.

Yu. D. Martsinyshyn, S. V. Pyda

Ternopil Volodymyr Hnatiuk National Pedagogical University, Ukraine

\section{BIOCHEMICAL COMPOSITION OF SOFT WHEAT GRAIN (TRITICUM AESTIVUM L.) UNDER THE INFLUENCE OF FERTILIZERS}

The article, based on the analysis of scientific works, presents the research findings of the influence of mineral, organic and organo-mineral fertilizer on the biochemical composition of soft wheat grain. It is shown that seed productivity and quality of wheat grain depend on the provision of plants with nutrients during the growth season, resistance to stress factors and biological characteristics of the variety. The yield of winter wheat increases due to super-strong and extra-strong varieties, but the quality of grain, which is negatively correlated with productivity, decreases.

Fertilizers are a significant factor in improving the quality of wheat grain, and their use allows to obtain high quality baking flour. Application of different types of organic fertilizers (cattle manure, chicken manure) and green manures (wheat-wheat, oat-pea, mustard) results in an increase in the gluten content from 24.2 to $25.6-27.7 \%$ in grain winter wheat. The application of manure also contributed to the accumulation of proteins in the grain. The quality of wheat grain (nutritional value ISSN 2078-2357. Наук. зап. Терноп. нац. пед. ун-ту. Сер. Біол., 2021, T. 81, № 1-2 
and baking properties) depends on both the protein content and their amino acid composition. Nitrogen fertilizers have been shown to increase the protein content and the amount of essential amino acids in grain and improve their amino acid composition, but their application, especially in higher doses, reduces the baking properties of wheat flour. The use of nitrogen fertilizers also increases the content of trace elements in wheat grain and improves the nutritional value of this important food. Foliar feeding of plants with chelated micro-fertilizers on the background of complete mineral nutrition $\left(\mathrm{N}_{60} \mathrm{P}_{60} \mathrm{~K}_{60}\right)$ also improves the quality of grain, while increasing the content of proteins and gluten.

Pre-sowing seed treatment and foliar fertilization of plants in the phase of tillering and earing with liquid organo-mineral fertilizer Polidon Bio Zernovyi special purpose for winter wheat, against the background of mineral nutrition $\left(\mathrm{N}_{60} \mathrm{P}_{60} \mathrm{~K}_{60}\right)$, increased the protein content in grain according to experimental variants and promoted raw gluten growth.

Keywords: soft wheat, grain biochemical composition, proteins, gluten, fertilizers.

Надійшла 19.05.2021. 